\title{
Perancangan Sistem Informasi Penerimaan Mahasiswa Baru Berbasis Web di FKIP UNIMUDA Sorong
}

\author{
Irmayani Abdul Salam, Muhummad Ihsan, Matahari \\ Universitas Pendidikan Muhammadiyah Sorong \\ Irmaas236@gmail.com
}

\begin{abstract}
Abstrak: Penelitian ini bertujuan untuk merancang sistem informasi penerimaan mahasiswa baru berbasis web yang mampu mengelola pelaksanaan Penerimaan Mahasiswa baru yaitu pendaftaran, verifikasi, dan pengumuman kelulusan, dan mengetahui valid, praktis, dan efektif sistem penerimaan mahasiswa baru di FKIP UNIMUDA Sorong. jenis penelitian ini adalah Research and Development dengan tahapan: 1)studi pustaka, 2)studi lapangan, 3)Observasi, 4).Desain Produk, 5)uji coba produk. Pendekatan yang digunakan terstruktur dengan metode pengembangan sistem informasi penerimaan mahasiswa baru berbasis web yang di rancang dengan menggunakan metode prototype. Pengujian perangkat lunak dilakukan melalui pengujian black-box, serta melalui uji coba skala kecil dan uji coba skala besar. Hasil peneitian menunjukkan bahwa sistem informasi penerimaan mahasiswa baru berbasis web ini mampu mengelola pelaksanaan penerimaan mahasiswa baru yaitu berupa pendaftaran, verifikasi dan pengumuman kelulusan. Berdasarkan hasil penelitian ini juga menunjukkan bahwa indikator aspek program dari validator yaitu dengan rerata 3,65 persentase 91,25\% ,indikator aspek conten dengan rerata3,60 persentase $90,00 \%$ dan indikator aspek pengguna dengan rerata 3,57 persentase $89,25 \%$, bahwa aspek program dinyatakan sangat valid. Maka aplikasi dapat digunakan atau valid menurut validator untuk diuji coba ketahap berikutnya, menunjukkan bahwa secara keseluruhan indikator pengguna aplikasi praktis memperoleh rerata dengan nilai 3,48 presentase $87,08 \%$ dengan kategori sangat praktis dan secara keseluruhan indikator pengguna aplikasi efektif memperoleh rerata 3,4 presentase $85 \%$ dengan kategori sangat efektif. Dapat disimpulkan bahwa sistem informasi penerimaan mahasiswa baru berbasis web dapat digunakan dengan praktis dan efektif dalam proses penerimaan mahasiswa baru di FKIP UNIMUDA Sorong..
\end{abstract}

Kata kunci : Sistem Informasi, mahasiswa, web, prototype.

\section{Pendahuluan}

Teknologi informasi berkembang seiring dengan meningkatnya kebutuhan masyarakat, dalam memasuki dunia globalisasi masyarakat mengenal teknologi semakin maju untuk mempermudah melakukan berbagai kegiatan dalam kehidupan. Kemajuan dibidang transportasi, komunikasi, kesehatan, pendidikan dan bidang lainnya merupakan contoh-contoh bahwa masyarakat semakin memerlukan teknologi dalam kehidupan manausia Mengingat akan pesatnya kemajuan teknologi yang sudah merambah kesemua bidang, serta pola kehidupan masyarakat yang sudah relatif maju. Sistem informasi yang berbasis web dapat dimanfaatkan sebagai saran peningkatan informasi.

Pasal 11 ayat (1) terdapat pernyataan "Pemerintah dan Pemerintah Daerah wajib memberikan layanan dan kemudahan, serta menjamin terselenggaranya pendidikan yang bermutu bagi setiap warga negara tanpa diskriminasi" (UU No. 20 Tahun 2003). Upaya pemerintah dalam melaksanakan amanat UUD 1945 dan UU No. 20 Tahun 2003 tersebut di atas antara lain dengan memanfaatkan kemajuan Teknologi Informasi 
dalam dunia pendidikan. Penerapan teknologi informasi tersebut dimaksudkan agar dapat terselenggara pendidikan yang bermutu bagi setiap warga negara.

Univeristas Pendidikan Muhamadiyah (UNIMUDA) Sorong adalah salah satu univeristas yang berada di papua barat. Saat ini UNIMUDA memliki 3 fakultas yaitu: Fakultas Sains dan Teknologi (FST), Fakultas Ilmu Sosial dan Fakultas Keguruan dan Ilmu Pendidikan yang memiliki 10 program studi yaitu: Pendidikan Biologi, Pendidikan Bahasa Indonesia, Pendidikan Bahasa Inggris, pendidikan Matematika, Pendidikan Pancasila dan Warga Kenegaraan, Pendidikan Jasmani, Pendidikan Guru Sekolah Dasar, Pendidikan Teknologi Informasi, Pendidikan Ilmu Pengetahuan Alam, dan Pendidikan Guru PAUD.

Univeristas Pendidikan Muhamadiyah (UNIMUDA) Sorong adalah salah satu univeristas yang berada di papua barat. Saat ini UNIMUDA memliki 3 fakultas yaitu: Fakultas Sains dan Teknologi (FST), Fakultas Ilmu Sosial dan Fakultas Keguruan dan Ilmu Pendidikan yang memiliki 10 program studi yaitu: Pendidikan Biologi, Pendidikan Bahasa Indonesia, Pendidikan Bahasa Inggris, pendidikan Matematika, Pendidikan Pancasisla dan Warga Kenegaraan, Pendidikan Jasmani, Pendidikan Guru Sekolah Dasar, Pendidikan Teknologi Informasi, Pendidikan Ilmu Pengetahuan Alam, dan Pendidikan Guru PAUD.

\section{Metode Penelitian}

Jenis penelitian yang digunakan adalah jenis penelitian dan pengembangan Research and Development (R\&D). Research and Development (R\&D) adalah suatu proses atau langkah-langkah untuk mengembangkan suatu produk baru atau menyempurnakan produk yang telah ada sehingga dapat dipertanggung jawabkan. Produk tersebut tidak selalu berbentuk hardware software tetapi program komputer untuk pengolahan data, pembelajaran di kelas, perpustakaan atau laboratorium, pelatihan, bimbingan, evaluasi, dan manajemen.

Tahap penelitian dalam perancangan sistem ini peneliti akan menggunakan model pengembangan Prototyping. Prototyping merupakan teknik pengembangan sistem yang menggunakan Prortotype untuk menggambarkan sistem sehingga pengguna sistem mempunyai gambaran pengembangan sistem yang akan dilakukannya.

Objek penelitian merupakan sasaran untuk mendapatkan data sesuai tujuan yang akan dibuktikan secara objektif, objek penelitian Sistem Informasi Penerimaan Mahasiswa Baru berbasis web adalah Mahasiswa dan panitia PMB FKIP (Fakultas Keguruan Ilmu Pendidikan) UNIMUDA Sorong.

\section{a. Teknik Pengumpulan Data}

Teknik pengumpulan data yang dugunakan dalam penelitian ini adalah dengan beberapa metode yaitu :

1.Studi Pustaka

Peneliti melakukan studi pustaka dengan cara membaca dan mempelajari bukubuku atau penelitian sejenis dan selain itu penulis juga melakukan pencarian/browsing di beberapa situs internet untuk mengumpulkan data-data dan informasi yang berkaitan dengan masalah yang di bahas dalam pembuatan sistem.

2.Studi Lapangan

Kegiatan studi lapangan dilakukan pengumpulan data yang berkaitan dengan pemograman sistem informasi khususnya bahasa pemograman $p h p$ karena sistem informasi ini menggunakan bahasa $p h p$ dalam membangun aplikasinya. Setelah mendapatkan informasi yang dibutuhkan dengan mencari software-software pendukung untuk membangun sistem informasi ini. Kegiatan ini merupakan tahapan penelitian yang bertujuan untuk menggali data-data yang dibutuhkan 
sehubungan dengan sistem informasi yang akan dibangun. Data-data tersebut meliputi informasi tentang sistem informasi penerimaan mahasiswa baru.

3.Observasi

Pengumpulan data yang dilakukan dengan mengamati sistem penerimaan mahasiswa baru di FKIP UNIMUDA Sorong yang meliputi Pendaftara, verifikasi dan pengumuman kelulusan.

b. Teknik Analisis Data

Teknik analisis data dalam penelitian ini menggunakan statistik deskriptif. Statistik deskriptif adalah statistik yang digunakan untuk menganalisis data dengan cara mendeskripsikan atau menggambarkan data yang telah terkumpul adanya tanpa bermaksud membuat kesimpulan yang berlaku untuk umum atau generalisasi kemudian statistik deskriptif yang digunakan dalam penelitian ini adalah penyajian data dengan tabel, perhitungan rata-rata, standar deviasi dan persentase. Untuk menghitung persentase hasil observasi menggunakan rumus persamaan 1 :

$$
P=\frac{\text { skor hasil pengumpulan data }}{\text { skor ideal }} \times 100 \%
$$

Keterangan:

$\mathrm{P}=$ angka persentase

Persamaan 1

Skor ideal $=$ skor tertinggi $\mathrm{x}$ jumlah responden $\mathrm{x}$ jumlah butir.

Skor ideal adalah skor yang ditetapkan dengan asumsi bahwa setiap pertanyaan memberi jawaban dengan skor tertinggi, selanjutnya dari seluruh data yang terkumpul disajikan dalam bentuk narasi kalimat, gambar-gambar dan juga distribusi persentase. Tahap penelitian pengembangan, dilakukan teknik analisis sesuai dengan maksud dan tujuan tahapan tersebut. Oleh karena analisis yang digunakan dalam penelitian ini adalah analisis deskriptif, yang mendeskripsikan hasil pengembangan, respon validator, dan hasil ujicoba. Oleh karena penelitian ini menggunakan sampel kecil dan tidak dipilih secara random, maka analisis data menggunakan statistik non parametrik. Analisis non parametrik digunakan sesuai dengan jenis data dan tujuan analisis yang ingin dicapai. Jenis analisis data tersebut diuraikan lebih rinci untuk menjawab setiap pertanyaan penelitian sebagai berikut:

1. Validitas

Kategori validitas setiap aspek atau keseluruhan aspek yang dinilai ditetapkan berdasarkan kriteria pengkategorian sebagai beriku:

Tabel 1 Kategori Validitas

\begin{tabular}{ccc}
\hline No & Interval & Kategori \\
\hline 1 & $>3,25 \mathrm{~s} / \mathrm{d} 4,0$ & Sangat valid \\
2 & $>2,25 \mathrm{~s} / \mathrm{d} 3,25$ & Valid \\
3 & $>1,75 \mathrm{~s} / \mathrm{d} 2,25$ & Kurang valid \\
4 & $1,0 \mathrm{~s} / \mathrm{d} 1,75$ & Tidak valid \\
\hline
\end{tabular}




\section{Penilaian praktis}

Kategori penilaian praktis atau menilai kemudahan penggunaan sistem informasi tesis berbasis web yang dinilai berdasarkan kriteria pengkategorian pada Tabel 2 kategori praktis.

Tabel 2 Kategori Praktis

\begin{tabular}{ccc}
\hline No & Interval & Kategori \\
\hline 1 & $>3,25 \mathrm{~s} / \mathrm{d} 4,0$ & Sangat praktis \\
2 & $>2,25 \mathrm{~s} / \mathrm{d} 3,25$ & Praktis \\
3 & $>1,75 \mathrm{~s} / \mathrm{d} 2,25$ & Kurang praktis \\
& $1,0 \mathrm{~s} / \mathrm{d} 1,75$ & Tidak praktis \\
\hline
\end{tabular}

Indikator untuk mengukur praktisan perancangan sistem informasi penerimaan mahasiswa baru dikembangkan 4 pertanyaan atau pernyataan pada Tabel 3 kisi-kisi indikator praktis.

Tabel 3 kisi-kisi indikator Praktis

\begin{tabular}{clc}
\hline NO & \multicolumn{1}{|c}{ Pernyataan } & $\begin{array}{c}\text { Nomor } \\
\text { Butir }\end{array}$ \\
\hline 1 & Penggunaan aplikasi secara bersamaan & 15 \\
2 & Penggunaan aplikasi mengefisienkan waktu & 16 \\
3 & Penggunaan aplikasi mengefisienkan PMB & 17 \\
& FKIP UNIMUDA Sorong & \\
\hline
\end{tabular}

2. Penilaian efektifitas

Kategori penilaian praktis atau menilai kemudahan penggunaan sistem informasi tesis berbasis web yang dinilai berdasarkan kriteria pengkategorian pada Tabel 4 kategori efektif.

Tabel 4 Kategori efektif

\begin{tabular}{ccc}
\hline No & Interval & Kategori \\
\hline 1 & $>3,25 \mathrm{~s} / \mathrm{d} 4,0$ & Sangat efektif \\
2 & $>2,25 \mathrm{~s} / \mathrm{d} 3,25$ & Efektif \\
3 & $>1,75 \mathrm{~s} / \mathrm{d} 2,25$ & Kurang efektif \\
4 & $1,0 \mathrm{~s} / \mathrm{d} 1,75$ & Tidak efektif \\
\hline
\end{tabular}

Indikator untuk mengukur efektifitas sistem informasi Penerimaan Mahasiswa Baru dikembangkan 3 pertanyaan atau pernyataan pada Tabel 5 kisi-kisi indikator efektif. 
Tabel 5 kisi-kisi indikator efektif.

\begin{tabular}{clc}
\hline No & \multicolumn{1}{c}{ Pernyataan } & $\begin{array}{c}\text { Nomor } \\
\text { Butir }\end{array}$ \\
\hline 1 & $\begin{array}{l}\text { Inputan/masukan aplikasi sesuai dengan } \\
\text { output/keluaran }\end{array}$ & 19 \\
2 & $\begin{array}{l}\text { Tidak terdapat kesalahan (error) pada saat } \\
\text { aplikasi dijalankan }\end{array}$ & 20 \\
3 & \begin{tabular}{l} 
Penginputan/data yg dimasukkan terselesaikan \\
\hline
\end{tabular} & 21 \\
\hline
\end{tabular}

\section{Hasil dan Pembahasan}

Hasil pengembangan sistem informasi penerimaan mahasiswa baru di FKIP UNIMUDA Sorong menggunakan model pengembangan prototyping yag terdapat pada metode pengembangan SDLC (system development life cycle), meliputi langkah analisis kebutuhan, perancangan, membangun prototype, evaluasi, perubahan perancangan.

Uji coba merupakan uji coba utama untuk mengukur kelayakan sistem informasi penerimaan mahasiswa baru yang dipergunakan dan diterapkan. Uji coba lapangan melibatkan 30 mahasiswa FKIP UNIMUDA Sorong yang terdiri dari: 10 mahasiswa prodi PGSD, 10 mahasiswa prodi PJKR, dan 10 mahasiswa prodi Matematika.

Uji coba terdiri dari 5 indikator yaitu : (1) kualitas sistem, (2) navigasi, (3) penggunaan aplikasi (praktis), (4) penggunaan aplikasi (efektif), (5) kepuasan pengguna dan (6) dampak bagi PMB FKIP UNIMUDA Sorong. Pengujian ini dimaksudkan untuk mengukur bagaimana kualitas sistem informasi yang dihasilkan tidak lagi membahas masalah konten pada sistem sehingga dapat diketahui kehandalan dan manfaat sistem yang akan diterapkan.

1) Indikator Kualitas Aplikasi/Sistem

Pada indikator ini ada 6 sub indikator untuk mengukur bagaimana kualitas sistem dalam penggunaannya. Penilaian dilakukan oleh 30 responden yang berasal dari 30 mahasiswa FKIP UNIMUDA Sorong yang terdiri dari: 10 mahasiswa prodi PGSD, 10 mahasiswa prodi PJKR, dan 10 mahasiswa prodi Matematika berdasarkan sub indikator yaitu : (1) mudah dipahami, (2) mudah digunakan, (3) memudahkan dalam proses pendaftaran, (4) memudahkan dalam proses penginputan data diri dan orang tua/wali, (5) memudahkan dalam proses penginputan nilai , (6) memudahkan dalam mendapatkan informasi pengumuman kelulusan,

Rangkuman hasil evaluasi responden pada indikator kualitas sistem ditunjukkan pada tabel 1. Hasil uji coba sub indikator (1) mudah dipahami memperoleh rerata 3,83 dan presentase $95,83 \%$ berada pada kategori sangat baik. Sub indikator (2) mudah digunakan memperoleh rerata 3,63 dan presentase $90,83 \%$ berada pada kategori sangat baik. Nilai rerata yang dihasilkan pada sub indikator 1 dan 2 dengan keduanya berkategori sangat baik menunjukkan bahwa sistem informasi yang telah diuji cobakan sangat mudah dipahami dan digunakan oleh pihak-pihak yang berkaitan dengan proses penerimaan mahasiswa baru. Sub 
indikator (3) mengenai memudahkan dalam proses pendaftaran memperoleh nilai dengan rerata 3,4 dan presentase $85 \%$ yang berarti kategori sangat baik ini menilai sistem memberikan kemudahan calon mahasiswa baru melakukan pendaftaran. Sub indikator (4) mengenai memudahkan dalam penginputan identias dan data orang tua/wali memperoleh nilai dengan rerata 3,6 dan 90\% yang berarti kategori sangat baik menilai sistem memberikan kemudahan kepada PMB FKIP UNIMUDA Sorong dalam menerimaan mahasiswa baru. Sub indikator (5) mengenai memudahkan penginputan nilai memperoleh nilai dengan rerata 3,46 dan presentase 86,66\% dengan kategori sangat baik. Sub indikator (6) mengenai memudahkan dalam proses informasi kelulusan memperoleh nilai 3,7 dan 92,5\% dengan kategori sangat baik.

Tabel 6 Indikator Kualitas Aplikasi/Sistem

\begin{tabular}{clccc}
\hline No & \multicolumn{1}{c}{ Aspek yang dinilai } & Rerata & Presentase & Keterangan \\
\hline 1 & Mudah dipahami & 3,83 & $95,83 \%$ & Sangat baik \\
2 & Mudah digunakan & 3,63 & $90,83 \%$ & Sangat baik \\
3 & $\begin{array}{l}\text { memudahkan dalam proses } \\
\text { pendaftaran }\end{array}$ & 3,4 & $85 \%$ & Sangat baik \\
4 & $\begin{array}{l}\text { memudahkan dalam penginputan } \\
\text { identias dan data orang tua/wali }\end{array}$ & 3,6 & $90 \%$ & Sangat baik \\
5 & $\begin{array}{l}\text { memudahkan dalam proses } \\
\text { penginputan nilai }\end{array}$ & 3,46 & $86,66 \%$ & Sangat baik \\
& $\begin{array}{l}\text { memudahkan dalam proses } \\
6\end{array}$ & 3,7 & $92,5 \%$ & Sangat baik \\
& $\begin{array}{l}\text { informasi kelulusan } \\
\text { Keseluruhan Indikator }\end{array}$ & $\mathbf{3 , 6 0}$ & $\mathbf{9 0 , 1 3 \%}$ & Sangat baik \\
\hline
\end{tabular}

Dataindikator kualitas aplikasi/sistem yang ditunjukkan pada tabel 6 diatas menunjukkan keseluruhan kualitas sistem memiliki rerata 3,60 dan presentase 90,13\% berada dalam kategori sangat baik, dapat disimpulkan bahwa keseluruhan indikator kualitas aplikasi/sistem sudah dapat dikatan baik. Uji coba dilakukan dengan cara menunjukkan kerja sistem informasi penerimaan mahasiswa baru. Pada uji coba ini semua responden dipersilahkan mengoperasikan dan bertanya tentang sistem informasi penerimaan mahasiswa baru yang di uji coba agar semua responden paham kualitas aplikasi/sistem yang diuji.Tingkat rerata skor penilaian indikator kualitas sistem/aplikasi dapat dilihat pada Gambar 1 


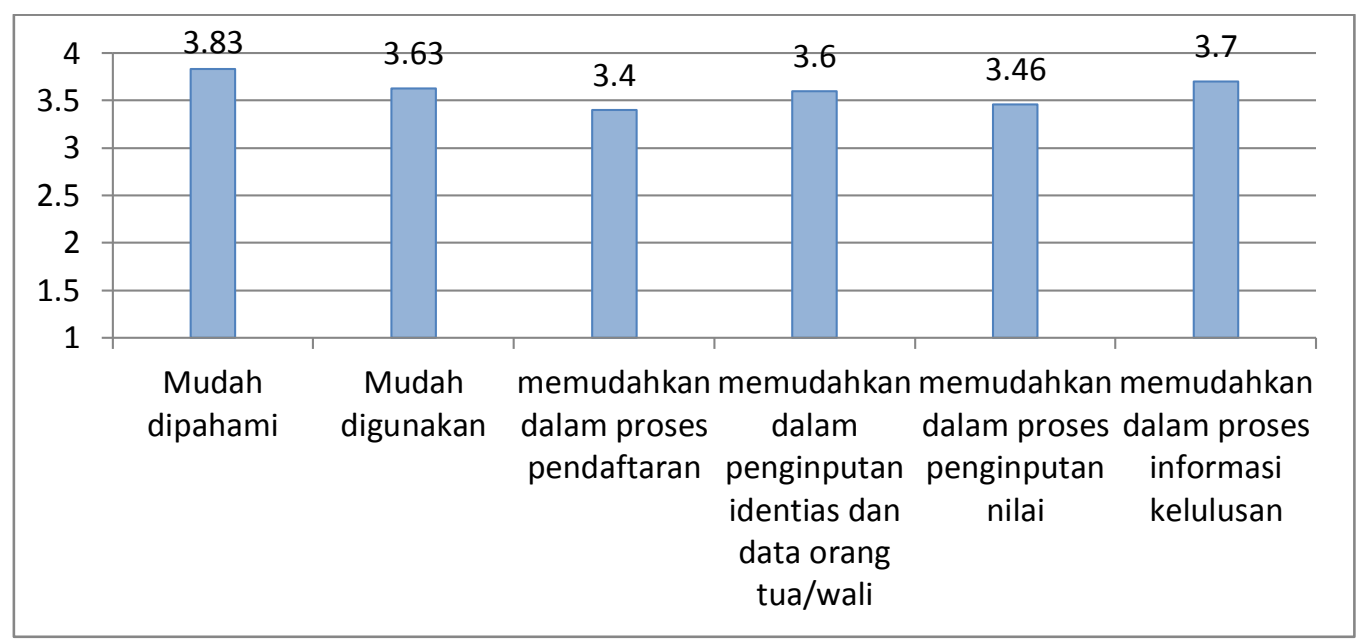

Gambar 1 Grafik Penilaian Kualitas Sistem

2) Indikator navigasi

Pada indikator ini mengukur fungsi menu yang ada pada sistem informasi sistem informasi penerimaan mahasiswa baru yang telah diuji coba, siap untuk digunakan. Indikator ini terbagi dari 5 sub indikator yaitu: (1) kemudahan memilih menu, (2) kemudahan menggunakan menu, (3) kemudahan menggunkan icon, (4) ada peringatan jika melakukan kesalahan login atau input data dan (5) kemudahan menginput dan menghapus data. Data dari hasil uji coba dapat dilihat pada Tabel 7

Tabel 8 Indikator Navigasi

\begin{tabular}{clccc}
\hline No & \multicolumn{1}{c}{ Aspek yang dinilai } & Rerata & Presentase & Keterangan \\
\hline 1 & Kemudahan memilih menu & 3,56 & $89,16 \%$ & Sangat baik \\
2 & Kemudahan penggunaan menu & 3,56 & $89,16 \%$ & Sangat baik \\
3 & $\begin{array}{l}\text { Ada peringatan jika melakukan } \\
\text { kesalahan login atau input data }\end{array}$ & 3,23 & $80,83 \%$ & Sangat baik \\
4 & $\begin{array}{l}\text { Kemudahan meng-input dan } \\
\text { menghapus data }\end{array}$ & 3,6 & $90 \%$ & Sangat baik \\
& Keseluruhan Indikator & $\mathbf{3 , 6 0}$ & $\mathbf{9 0 , 1 3 \%}$ & Sangat baik \\
\hline & Pada tabel 8 dapat digambarkan & pada & sub indikator & (1) kemudahan
\end{tabular}

memilih menu dikategorikan sangat baik dengan nilai rerata 3,56 dan presentase $89,16 \%$. Hal ini menunjukkan menu-menu yang terdapat pada sistem informasi penerimaan mahasiswa baru mudah digunakan oleh responden sangat baik, pada sub indikator (2) kemudahan menggunakan menu dikategorikan sangat baik dengan nilai rerata 3,56 dan presentase $89,16 \%$. Hal ini menunjukkan kemudahan memilih menu pada sistem sangat baik, sub inidkator(3) ada peringatan jika melakukan kesalahan login atau input data dikategorikan sangat baik dengan nilai rerata 3,23 dan presentase $80,83 \%$. Hal ini menunjukkan dalam mengurangi kesalahan pengguna sistem peringatan berfungsi dengan sangat baik dan sub indikator (4) kemudahan meng-input dan menghapus data dikategorikan sangat baik dengan nilai rerata 3,6 dan presentase 90\%. Hal ini menunjukkan dalam proses penghapusan data sistem dapat berfungsi dengan sangat baik. 
Pada Tabel 8 menunjukkan bahwa secara keseluruhan indikator memperoleh rerata 3,60 dan presentase 90,13\% dengan kategori sangat baik. Dapat disimpulkan berdasarkan hasil keseluruhan indikator navigasi bahwa navigasi pada sistem informasi tesis sesuai dengan kebutuhan yang telah diuji coba kelompok besar dan sudah dapat digunakan di PMB FKIP UNIMUDA Sorong.Tingkat rerata skor penilaian indikator navigasi pada uji coba dapat dilihat pada Gambar 2

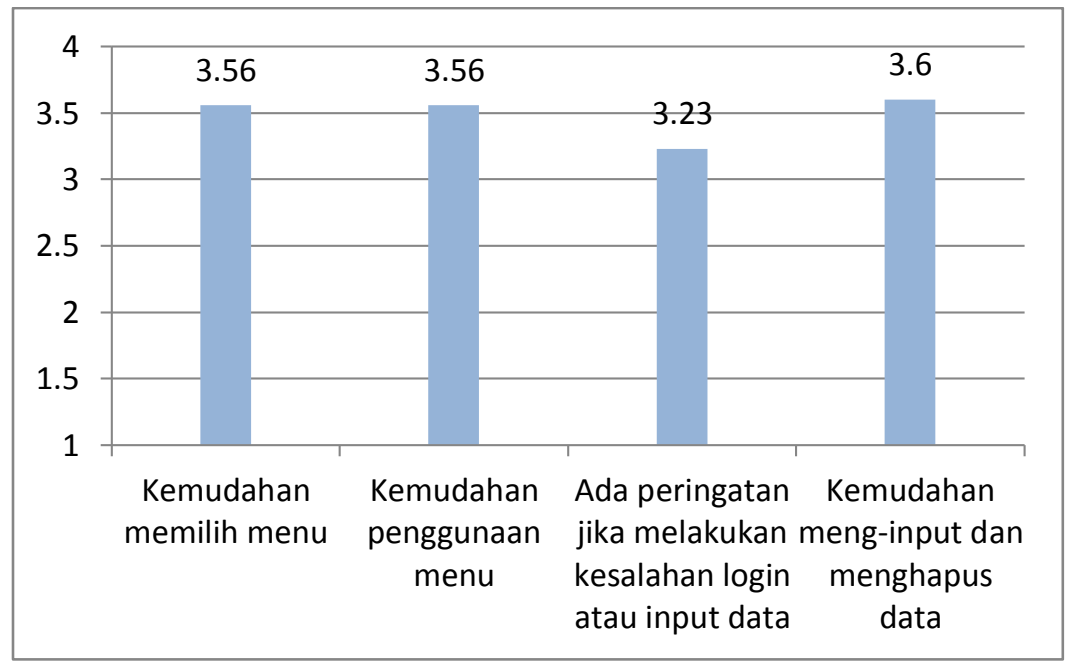

Gambar 2 Grafik Penilaian Navigasi Sistem

3) Indikator penggunaan aplikasi (praktis)

Pada indikator ini mengukur sistem informasi sistem informasi penerimaan mahasiswa baru tesis yang telah diuji coba siap digunakan, indikator ini terbagi dari 4 sub indikator yaitu: (1) penggunaan aplikasi secara bersamaan, (2) penggunaan aplikasi mengefisienkan waktu, (3) penggunaan sistem mengefisienkan tempat pendaftaran, dan (4) penggunaan aplikasi diberbagai hardware dan software yang ada. Data dari hasil uji coba dapat dilihat pada Tabel 9

Tabel 9 Indikator Penggunaan Aplikasi (Praktis)

\begin{tabular}{clccc}
\hline No & \multicolumn{1}{c}{ Aspek yang dinilai } & Rerata & Presentase & Keterangan \\
\hline 1 & $\begin{array}{l}\text { Penggunaan aplikasi secara } \\
\text { bersamaan }\end{array}$ & 3,43 & $85,83 \%$ & $\begin{array}{l}\text { Sangat } \\
\text { Praktis } \\
2\end{array}$ \\
$\begin{array}{l}\text { Pengunaan aplikasi } \\
\text { mengefisienkan waktu }\end{array}$ & 3,33 & $83,33 \%$ & $\begin{array}{l}\text { Sangat } \\
\text { praktis }\end{array}$ \\
3 & $\begin{array}{l}\text { Penggunaa aplikasi } \\
\text { mengefisienkan tempat } \\
\text { pendaftaran }\end{array}$ & 3,63 & $90,83 \%$ & $\begin{array}{l}\text { Sangat } \\
\text { praktis }\end{array}$ \\
& $\begin{array}{l}\text { Penggunaan apliksi di berbagai } \\
\text { hardware dan softrware yang ada }\end{array}$ & 3,53 & $88,32 \%$ & $\begin{array}{l}\text { Sangat } \\
\text { praktis } \\
\text { Sangat } \\
\text { praktis }\end{array}$ \\
\hline
\end{tabular}

Tabel 9 dapat digambarkan pada sub indikator (1) penggunaan aplikasi secara bersamaan dikategorikan sangan baik dengan nilai rerata 3,43 dan 
presentase $85,83 \%$. Hal ini menunjukkan bahwa penggunaan sistem informasi penerimaan mahasiswa baru dapat dilakukan secara bersamaan tanpa menggangu pengguna yang lainnya.

Selanjutnya pada sub indikator (2) penggunaan aplikasi mengefisienkan waktu dikategorikan sangat praktis dengan nilai rerata 3,33 dan presentase 83,33\% . Hal ini menunjukkan bahwa penggunaan sistem informasi penerimaan mahasiswa baru dapat menghemat waktu yang dibutuhkan dalam proses pendaftran jauh lebih cepat. Sub indikator (3) penggunaan aplikasi mengefisienkan tempat pendaftaran dikategorikan sangat praktis dengan nilai rerata 3,63 dan presentase 90,83\% . Hal ini menunjukkan penggunaan sistem informasi penerimaan mahasiswa baru dapat mengefisienkan tempat penerimaan mahasiswa baru. Sub inikator (4) penggunaan aplikasi di berbagai hardware dan software yang ada dikategorikan sangat praktis dengan nilai rerata 3, 53 dan presentase $88,32 \%$. Hal ini menunjukkan penggunaan aplikasi tidak memerlukan spesifikasi khusu untuk di diterapkan dan digunakan.

Tabel 9 menunjukkan bahwa secara keseluruhan indikator memperoleh rerata dengan nilai 3, 48 dan presentase $87,08 \%$ dengan kategori sangat praktis sehingga dapat disimpulkan bahwa sistem informasi sistem informasi penerimaan mahasiswa baru tesis siap diterapkan dan digunakan pada PMB FKIP UNIMUDA Sorong, dalam penggunaannya hanya boleh digunakan mahasiswa FKIP UNIMUDA Sorong. Tingkat rerata skor penilaian indikator penggunaan sistem secara praktis pada uji coba dapat dilihat pada Gambar 3 dibawah ini:

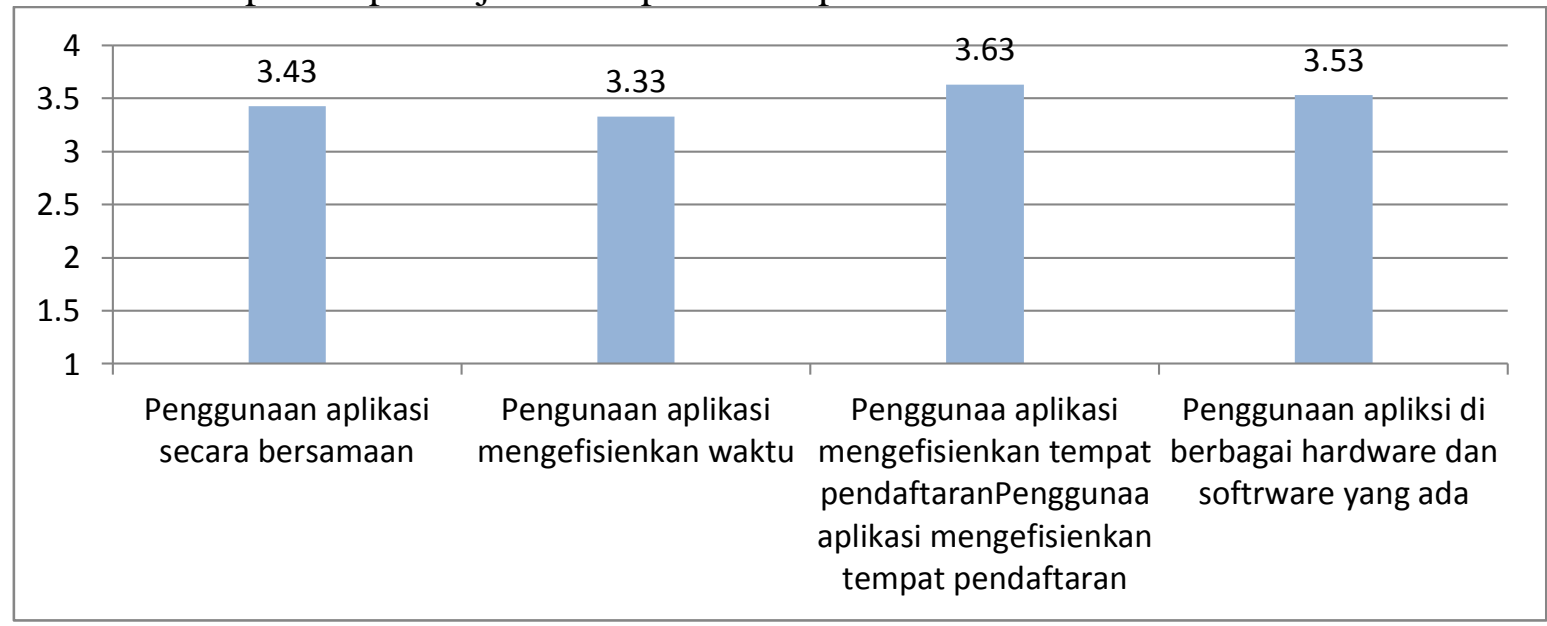

Gambar 3 Grafik Penilaian Penggunaan Sistem secara Praktis

4) Indikator penggunaan aplikasi (efektif)

Tabel 10 Indikator Penggunaan Aplikasi (Efektif)

\begin{tabular}{clccc}
\hline No & \multicolumn{1}{c}{ Aspek yang dinilai } & Rerata & Presentase & Keterangan \\
\hline 1 & $\begin{array}{l}\text { Input/masukan aplikasi sesuai } \\
\text { dengan } \text { output/keluaran }\end{array}$ & 3,5 & $87,5 \%$ & Sangat efektif \\
2 & $\begin{array}{l}\text { Tidak terdapat kesalahan (eror) } \\
\text { pada saat aplikasi dijalankan }\end{array}$ & 3,53 & $88,32 \%$ & Sangat efektif \\
3 & $\begin{array}{l}\text { Penginputan atau data yang } \\
\text { dimasukkan diproses } \\
\text { (terselesaikan) }\end{array}$ & 3,5 & $87,5 \%$ & Sangat efektif
\end{tabular}


Indikator ini mengukur sistem informasi sistem informasi penerimaan mahasiswa baru tesis yang telah diuji coba penggunaan aplikasi secara efektif siap untuk digunakan. Indikator pada penggunaan aplikasi secara efektif terbagi menjadi 3 sub indikator yaitu: (1) input/masukan aplikasi sesuai dengan output/keluaran, (2) tidak terdapat kesalahan (error) pada saat aplikasi dijalankan dan (3) penginputan data yang dimasukkan di prosees (terselesaikan). Data dari hasil uji coba kelompok besar atau diperluas dapat dilihat pada Tabel. 4.16

Tabel 4 dapat digambarkan pada sub indikator (1) input/masukan aplikasi sesuai dengan output/keluaran dikategorikan sangat baik dengan nilai rerata 3,5 dan presentase $87,5 \%$. Hal ini menunjukkan bahwa masukan dan keluaran sistem berjalan sesuai dengan proses sistem informasi penerimaan mahasiswa baru tesis. Sub indikator (2) tidak terdapat kesalahan (error) pada saat aplikasi dijalankan dikategorikan sangat baik dengan nilai rerata 3,53 dan presentase $88,32 \%$. Hal ini menunjukkan bahwa sistem informasi penerimaan mahasiswa baru tidak terdapat kesalahan atau eror.Sub indikator (3) penginputan atau datayang dimasukkan di proses (terselesaikan) dikategorikan sangat baik dengan nilai rerata 3,5 dan presentase $87,5 \%$. Hal ini menunjukkan bahwa sistem informasi penerimaan mahasiswa baru mampu menerima masukan dan melakukan pemrosesan data dengan baik.

Tabel 10 menunjukkan bahwa secara keseluruhan indikator memperoleh rerata dengan nilai 3,51 dan presentase $87,77 \%$ dengan kategori sangat efektif. Dapat disimpulkan bahwa sistem informasi penerimaan mahasiswa baru dapat digunakan dengan sangat efektif dalam proses PMB FKIP UNIMUDA Sorong. Tingkat rerata skor penilaian indikator penggunaan sistem secara efektif dapat dilihat pada Gambar 4

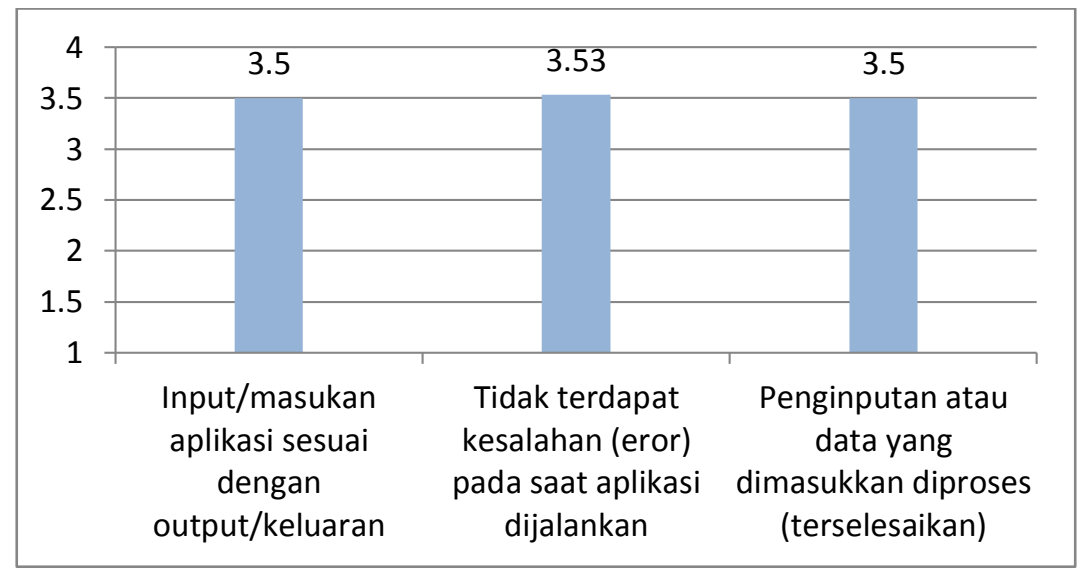

Gambar 4 Indikator Penggunaan Aplikasi (Efektif)

5) Indikator Kepuasan Pengguna

Indikator kepuasan pemakai merupakan indikator yang digunakan untuk mengukur kepuasan pemakai dalam menggunakan sistem informasi penerimaan mahasiswa baru yang telah di uji coba. Uji coba dilakukan kepada 30 responden. Indikator kepuasan terdiri dari 1 sub indikator yaitu. Puas terhadap hasil aplikasi 
yang telah dirancang. Rangkuman hasil uji coba diperluas dapat dilihat pada Tabel 11.

Tabel 11 Indikator Kepuasan Pengguna

\begin{tabular}{clccc}
\hline No & \multicolumn{1}{c}{ Aspek yang dinilai } & Rerata & Presentase & Keterangan \\
\hline 1 & $\begin{array}{l}\text { Puas terhadap hasil aplikasi yang } \\
\text { telah dirancang }\end{array}$ & 3,8 & $95 \%$ & Sangat baik \\
& Keseluruhan Indikator & $\mathbf{3 , 8}$ & $\mathbf{9 5 \%}$ & Sangat baik \\
\hline
\end{tabular}

Tabel 11 dapat disimpulkan sub indikator puas terhadap hasil aplikasi yang telah dikembangkan memperoleh nilai rerata 3,8 dan presentase 95\% dengan kategori sangat baik, hal ini menunjukkan penerapan dan penggunaan sistem informasi penerimaan mahasiswa baru berbasis web berhasil memberikan kepuasan terhadap calon mahasiswa PMB FKIP UNIMUDA Sorong.

6) Indikator Dampak Bagi PMB FKIP UNIMUDA Sorong

Indikator dampak bagi PMB FKIP UNIMUDA Sorong merupakan indikator yang digunakan untuk mengukur keberdayagunaan atau manfaat sistem informasi penerimaan mahasiswa baru terhadap penerapannya. Indikator ini terdiri dari 2 sub indikator yaitu: (1) menghemat tenaga, waktu dan biaya (praktis) dan(2) membantu proses pelaksanaan sistem informasi penerimaan mahasiswa baru tesis menjadi (efektif). Rangkuman nilai dari hasil uji coba kelompok besar dapat dilihat pada tabel 12 .

Tabel 12 Indikator Dampak Bagi PMB FKIP UNIMUDA Sorong

\begin{tabular}{clccc}
\hline No & \multicolumn{1}{c}{ Aspek yang dinilai } & Rerata & Presentase & Keterangan \\
\hline 1 & $\begin{array}{l}\text { Menghemat tenaga, waktu dan } \\
\text { biaya (praktis) }\end{array}$ & 3,76 & $94,16 \%$ & Sangat baik \\
2 & $\begin{array}{l}\text { Membantu proses pelaksanaan } \\
\text { sistem informasi penerimaan } \\
\text { mahasiswa baru tesis menjadi } \\
\text { efektif }\end{array}$ & 3,83 & $95,83 \%$ & Sangat baik \\
& & & & \\
Keseluruhan Indikator & $\mathbf{3 , 8}$ & $\mathbf{9 5 \%}$ & Sangat baik \\
\hline
\end{tabular}

Berdasarkan Tabel 12 maka dapat diuraikan bahwa sub indikator (1) menghemat tenaga, waktu dan biaya (praktis) memperoleh nilai rerata 3,76 dan presentase $94,16 \%$ dengan kategori sangat baik. Selanjutnya untuk sub indikator (2) membantu proses pelaksanaan sistem informasi penerimaan mahasiswa baru tesis menjadi efektif memperoleh nilai rerata 3,83 dan presentase 95,83\% dengan kategori sangat baik. dilihat pada Gambar 5 


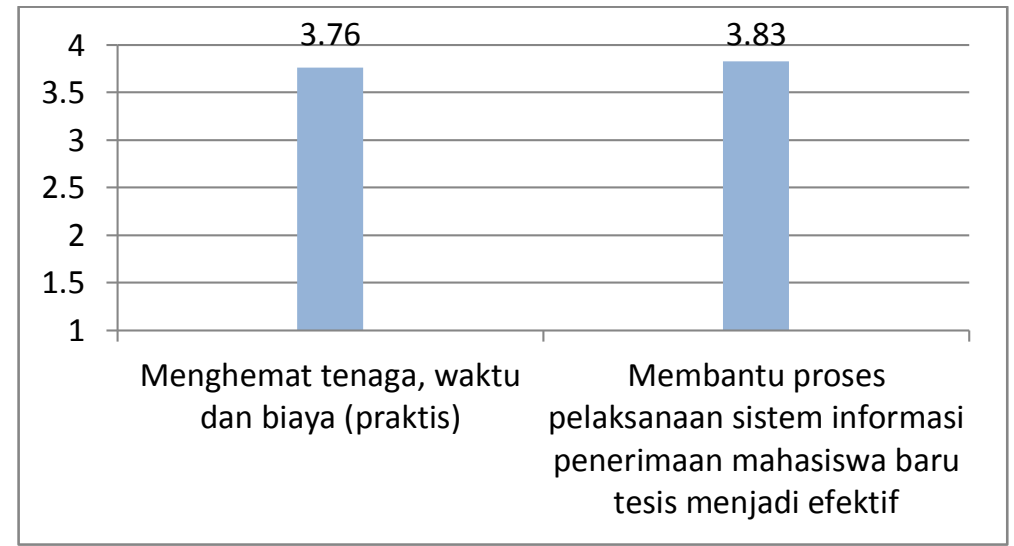

Gambar 5 Grafik Penilaian Dampak Bagi PMB

Dapat simpulkan secara keseluruhan indikator dampak bagi PMB FKIP UNIMUDA Sorong berada pada kategori sangat baik dengan rerata 3,8 dan presentase $95 \%$. Ini menunjukkan bahwa sistem informasi penerimaan mahasiswa baru yang dierapkan dan yang diuji coba memberikan manfaat bagi PMB FKIP UNIMUDA Sorong.

\section{Kesimpulan dan Saran}

Perancangan Sistem Informasi Penerimaan Mahasiswa Baru Berbasis Web di FKIP UNIMUDA Sorong, telah berhasil dirancang dengan Notepad ++ dan basis data mengunakan MySQL. Sistem ini praktis dan efektif kepada user khususnya calon mahasiswa baru sehingga mendapatkan kemudahan dalam melakukan pendaftaran tanpa harus datang di FKIP UIMUDA Sorong.

Berdasarkan seluruh hasil penelitian dapat disimpulkan bahwa indikator aspek program dengan rerata 3,65 dan presentase $91,25 \%$ bahwa aspek program dari sistem informasi penjualan sangat valid, indikator aspek content dengan rerata 3,60 dan presentase $90,00 \%$ bahwa aspek program sangat valid dan indikator aspek pengguna dengan rerata 3,57 dan presentase $89,25 \%$ bahwa aspek program sangat valid. Maka aplikasi dapat digunakan atau valid menurut validator untuk diuji coba ketahap berikutnya, berupa uji coba kelompok kecil dan uji coba kelompok besar menunjukkan bahwa secara keseluruhan indikator pengguna aplikasi praktis memperoleh rerata dengan nilai 3,48 dan presentase 87,08\% dengan kategori sangat praktis sehingga dapat disimpulkan bahwa sistem informasi penerimaan mahasiswa baru siap diterapkan dan digunakan di FKIP UNIMUDA Sorong, dan pada pada kategori efektif menunjukkan bahwa secara keseluruhan indikator pengguna aplikasi efektif memperoleh rerata3,51 dan presentase $87,77 \%$ dengan kategori sangat efektif. Dapat disimpulkan bahwa sistem informasi penjualan dapat digunakan dengan efektif dalam proses pendaftaran di FKIP UNIMUDA Sorong.

Saran-saran yang dapat penulis berikan yang sekiranya bermanfaat adalah sebagai berikut:

1. Untuk pengembangan sistem informasi penerimaan mahasiswa baru diharapkan untuk mengembangkan design web agar lebih menarik dari yang telah dirancang. 
2. Diharapkan dapat mengembangkan sistem informasi penerimaan mahasiswa baru ini tidak hanya dalam penerimaan melainkan bisa sekligus dilakukannya tes seleksi online.

\section{Daftar Pustaka}

Abdulloh, R. (2016). Web Programming. Jakarta: PT Alex Media Komputindo.

Abdulloh, R. (2018). 7 in 1 Pemograman Web untuk Pemula. Jakarta: PT Elex Media Komputindo.

Anggraeni, E. Y. (2017). Pengantar Sistem Informasi (E. Risanto, ed.). Yogyakarta.

Didik Setiawan. (2018). Pemrograman Web. Yogyakarta: START UP.

Enterprise, J. (2014). MySQL untuk Pemula. Jakarta: PT Elex Komputindo.

Enterprise, J. (2017). PHP Komplit. Jakarta: PT Alex Media Komputindo.

Hutahaean, J. (2014). Konsep Sistem Informasi. Yogyakarta: CV BUDI UTAMA.

Josi, A. (2017). DESA ( STUDI KASUS DESA SUGIHAN KECAMATAN RAMBANG ) STMIK-MUSIRAWAS LUBUKLINGGAU. 9(1).

Krisianto, A. (2014). Internet Untuk pemula. Jakarta: PT Alex Media Komputindo.

Kristanto, A. (2018). Perancangan Sistem Informasi dan Aplikasinya. Yogyakarta: Gava Media.

Palevi, A. R. (2013). ANALISIS DAN PERANCANGAN SISTEM INFORMASI PENERIMAAN PESERTA DIDIK BARU BERBASIS WEBSITE PADA SMP NEGERI 2 MOJOSONGO Pendahuluan Landasan Teori \& Tinjauan Umum. Ilmiah DASI, 14(04), 2-7.

Prof.Dr.Sugiyono.(2015). Metode Penelitian dan Pengembangan (Research and Development). Bandung: Alfabeta

Raharjo, B. (2016). Modul Pemograman Web. Bandung: Modula.

Randi. (2015). Rancangan Sistem Informasi Keuangan Gereja Berbasis Web Di Jemaat GMIM Bukit Moria Malalayang. Teknik Elektro Dan Komputer, 4(7), $1-7$.

Rerung, R. R. (2018). Pemograman Web Dasar. Yogyakarta: CV Budi Utama.

Setiawan, D. (2018). Pemrograman Web. yogyakarta: START UP.

Sri Mulyani. (2016). Metode Analisis dan Perancangan. Bandung: Abdi Sistematika.

Supono. (2018). Pemrograman web dengan menggunakan PHP dan Framework Codeigniter. Yogyakarta: CV Budi Utama.

Wodoyoko, E. (2016). Evaliuasi Program Pembelajaran. Yogyakarta: Pustaka Pelajar 
Jurnal PETISI, Vol. 1, No. 1

ISSN: - e-ISSN: - 